Article

\title{
The Green Experiment: Cities, Green Stormwater Infrastructure, and Sustainability
}

\author{
Christopher M. Chini ${ }^{1}$, James F. Canning ${ }^{1}$, Kelsey L. Schreiber ${ }^{1}$, Joshua M. Peschel ${ }^{2, *}$ and \\ Ashlynn S. Stillwell ${ }^{1}$ \\ 1 Department of Civil and Environmental Engineering, University of Illinois at Urbana-Champaign, \\ 2521 Hydrosystems Lab, 205 N. Mathews Ave., Urbana, IL 61801, USA; cchini2@illinois.edu (C.M.C.); \\ jcannin2@illinois.edu (J.F.C.); klschre2@illinois.edu (K.L.S.); ashlynn@illinois.edu (A.S.S.) \\ 2 Department of Agricultural and Biosystems Engineering, Iowa State University, 2348 Elings Hall, \\ 605 Bissell Road, Ames, IA 50011, USA \\ * Correspondence: peschel@iastate.edu; Tel.: +1-515-357-7448
}

Academic Editor: Tan Yigitcanlar

Received: 29 November 2016; Accepted: 7 January 2017; Published: 12 January 2017

\begin{abstract}
Green infrastructure is a unique combination of economic, social, and environmental goals and benefits that requires an adaptable framework for planning, implementing, and evaluating. In this study, we propose an experimental framework for policy, implementation, and subsequent evaluation of green stormwater infrastructure within the context of sociotechnical systems and urban experimentation. Sociotechnical systems describe the interaction of complex systems with quantitative and qualitative impacts. Urban experimentation-traditionally referencing climate change programs and their impacts-is a process of evaluating city programs as if in a laboratory setting with hypotheses and evaluated results. We combine these two concepts into a singular framework creating a policy feedback cycle (PFC) for green infrastructure to evaluate municipal green infrastructure plans as an experimental process within the context of a sociotechnical system. After proposing and discussing the PFC, we utilize the tool to research and evaluate the green infrastructure programs of 27 municipalities across the United States. Results indicate that green infrastructure plans should incorporate community involvement and communication, evaluation based on project motivation, and an iterative process for knowledge production. We suggest knowledge brokers as a key resource in connecting the evaluation stage of the feedback cycle to the policy phase. We identify three important needs for green infrastructure experimentation: (i) a fluid definition of green infrastructure in policy; (ii) maintenance and evaluation components of a green infrastructure plan; and (iii) communication of the plan to the community.
\end{abstract}

Keywords: green infrastructure; urban water policy; urban experiments; sociotechnical systems

\section{Introduction}

Cities are not static; they are constantly in a state of flux [1]. Within the past decade, global citizenship shifted from a predominantly rural population to a majority of the Earth's citizens living in urban environments [2]. Accompanying this shift in population is a growing struggle for cities to meet sustainability expectations as put forth by the United Nations in Local Agenda 21 [3]. Cities sit at a confluence of technology, resource consumption, population, culture, and economics, placing them in a unique position to tackle sustainability concerns. Sustainability agendas in cities are part of sociotechnical transitions, and require long-term policy consideration [4]. Water in the urban environment has transitioned through several states throughout its history: (i) water supply city; (ii) sewered city; (iii) drained city; (iv) waterways city; (v) water cycle city; and, finally, (vi) a water sensitive city [5]. The final state of transition—-the water sensitive city—is part of a larger sociotechnical 
landscape shift towards sustainable urban development. The current shift to sustainable development is a major objective and driving force for urban planning and policy [6]. One of these sustainability agendas occurs due to large amounts of impervious areas associated with cities, creating persistent stormwater concerns. Practices in the 20th century created a sociotechnical regime of a gray stormwater system with gutters, pipes, and concrete spillways to collect and remove stormwater as quickly as possible from the city [7]. This practice is often not a sustainable solution, leading to combined sewer overflows, basement flooding, and polluted runoff. A transition from a gray stormwater system to an integrated green-gray hybrid system is required to move towards the goal of urban stormwater sustainability.

These types of sociotechnical transitions can be enabled through a multilevel perspective: from the niche, to the regime, to the landscape [8]. These three levels of a sociotechnical approach to transitions have been discussed in many forums [8-14]. Niches are the often small collectives where radical innovations sometimes form and attempt to become widespread [8]. A sociotechnical landscape is the broader societal fabric that provides the foundation for potential change [4]. In contrast, sociotechnical regimes are the locations in which research and policy intersect and react [4]. Sociotechnical transition theorists originally investigated niches as the most important unit of analysis due to their role in innovation [14-16]; however, research has begun focusing on the sociotechnical regime. Regimes are the existing sociotechnical pattern throughout society, and generally evolve at a slow or static rate [14]. Regimes are critical components, as they define the exchanges within a sociotechnical system [16]. In the case of the urban environment, the broader sociotechnical landscape is moving from traditional 20th century planning and engineering principles to a sustainable design framework. Green infrastructure is one artifact that arose out of the niches and is in the process of transitioning the stormwater management regime in line with the broader urban landscape of sustainability-focused design. Urban experimentation is a means to facilitate the transition from niche development and between regimes [15,17].

Bulkeley and Broto [18] define urban experiments as intentional interventions within the sociotechnical fabric of the city to respond to issues of sustainability. While this definition was originally given within the context of climate change mitigation, we generalize the definition for applicability to any sociotechnical intervention within a city, including green infrastructure. Urban experiments allow for the scaling of technological and engineering innovation from an individual project to the city-level $[19,20]$, which is necessary to create a sustainable integrated green-gray stormwater infrastructure system. These experiments are a form of governance helping to steer change [18], inform wider policies to facilitate further sociotechnical transition [4], and make distant sustainability targets into realistic and achievable actions [21]. Urban experiments involve practice, policy, engineering, governance, and theory [22], and are sites of social learning [23].

In this study, we argue that a sociotechnical regime change is necessary in stormwater management, and an iterative, experimental approach is required for this regime change. The regime of gray infrastructure systems is rooted in the 20th century, and requires advancement through long-term policy towards a sustainable future. We propose urban experimentation as the means to promote the sociotechnical system of green infrastructure and a regime shift in stormwater management. Our study provides an engineering perspective on urban experimentation as a tool for the promotion of sustainable green infrastructure. We evaluate the green infrastructure plans of 27 cities across the United States to analyze their use of urban experimentation principles. Our study culminates in a discussion about the experimentality of green infrastructure (or the suitability of green infrastructure as an experiment), and its merits in promoting a sustainable approach to managing stormwater. 


\section{Background}

\subsection{Sustainability Policy}

Cities are often the focus for sustainability, as urban initiatives and efforts determine the relative success of the quest for sustainability [24]. Sustainability in the urban environment is both a process and a goal [25]. Time horizons for sustainability transitions require both short and long term action [4]. The varying time horizons for sustainability require an adaptive policy framework that is a part of the system and directly influence the functioning of the system [26,27]. Voß et al. [4] proposed long-term policy as a framework to promote sustainability in cities. Long-term policy for sustainability is embedded in the sociopolitical and sociotechnical processes it seeks to influence [28], and requires an integrated learning between stakeholders and policymakers [29]. Sustainability goals have an important role in the governance of cities as they strive to address sustainability challenges [30]. Additionally, the governance of sustainability unites cities in a common set of challenges [4], allowing for comparative sustainability studies. Along with long-term policies, these challenges create opportunities for short term experiments to complement sustainability initiatives and facilitate transitions toward a sustainable future [4].

\subsection{Green Infrastructure}

One aspect of urban sustainability comes in the form of managing stormwater runoffan increasingly challenging issue with the rising amount of impervious area in dense urban environments. Increased political, social, and environmental pressures force planners and engineers to help mitigate the number and severity of basement floodings or combined sewer overflows and improve receiving water quality. Handling both sewage and stormwater flows, combined sewer systems (CSS) are prevalent throughout many older municipalities in the United States [31]. These systems carry large risks for overflow, and high costs to municipal governments for full remediation. Essentially, large rainfall events can cause CSSs to overflow, discharging untreated sewage and stormwater into receiving waterbodies. The U.S. Environmental Protection Agency (EPA) regulates combined sewer overflows (CSOs) under the authority of the Clean Water Act (CWA). In 2004, the EPA issued a report to Congress on the widespread nature of CSOs, citing 746 communities in the United States that use CSSs [31]. The literal greening of the urban environment with vegetation (in the form of green infrastructure) provides opportunities for both reducing urban runoff volume and improving its quality.

Green infrastructure has multiple definitions within a common understanding of the system. Benedict and McMahon [32] define green infrastructure as "an interconnected network of green space that conserves natural ecosystem values and functions". Our paper narrows this definition to focus on a stormwater perspective of green infrastructure. A 2007 Memorandum by the EPA provides a definition of green stormwater infrastructure as approaches that infiltrate, evapotranspire, or reuse water as opposed to traditional hardscape conveyance (gray) infrastructure [33]. Expanding on these definitions, green infrastructure is stormwater infrastructure that utilizes natural processes such as infiltration to reduce, slow down, and clean runoff (e.g., green roofs, bioswales, rain gardens, and permeable pavement) [34]. Gray infrastructure-as opposed to its green counterpart-is the traditional means of engineering that utilizes concrete pipes and centralized treatment to remove stormwater as quickly as possible. Studies across the country have shown that expanding sewer services via green infrastructure is economically preferred and provides environmental benefits $[35,36]$.

In addition to water quality and quantity improvements, green infrastructure provides multiple benefits outside of these physical benefits. Through increased amounts of green spaces, green infrastructure provides social benefits to promote a sense of community, public health, and mental health [37-41]. The economic benefits of green infrastructure include increased property values and lower costs compared to comparable gray infrastructure expansion [42-44]. Environmental and ecological benefits include improved air quality and reduced urban heat island effects [45-47]. 
Additionally, there is a link between various forms of green infrastructure and energy savings [48,49]. It is important to consider both the qualitative and quantitative aspects of these spaces in any green infrastructure assessment $[37,50,51]$.

The combination of the environmental, social, and economic benefits of green infrastructure requires an integrative approach to planning, implementation, and evaluation within the context of a sociotechnical system. Additionally, due to green infrastructure's ecological benefits, the system may also be considered a socio-ecological system providing ecological resilience benefits (e.g., [52,53]). However, we choose to focus on the sociotechnical nature of green infrastructure. Green infrastructure strategies are not a one-size-fits-all approach $[54,55]$, and ad hoc interventions are no longer sufficient to promote a coordinated city-wide strategy for sustainability transitions [56]. There is a vast range of choices for sustainable green initiatives that requires an extensive array of case studies rooted in an experimental framework for comparison and evaluation [1]. Additionally, these green infrastructure strategies require long-term and short-term evaluation strategies to utilize the infrastructure as a means to support sustainable development [57]. Therefore, we propose an evaluation and implementation framework for green infrastructure using sociotechnical systems theory, requiring an urban experimental framework for the advancement of stormwater sustainability.

\subsection{Sociotechnical Systems and Transitions}

Before a discussion about sociotechnical transitions and their implications in sustainability, it is necessary to define terms. Sociotechnical systems have a long-standing history dating back to work in coal mines after World War II [58]. The phrase "sociotechnical system" was coined by Emery [59] to describe systems that have complex interactions between both human and non-human components (mainly machines). Badham et al. [60] define five key characteristics for sociotechnical systems: (i) have interdependent parts; (ii) experience stress from the external environment and have goals within that environment; (iii) have separate but interconnected social and technical subsystems; (iv) require decision-making to achieve goals; and (v) have performance based on optimizing social and technical subsystems. These five characteristics—while originally applied to industrial engineering and industrial psychology practices-have intentionally vague characteristics, allowing the applicability of the framework for many different systems, including green infrastructure.

Lawhon and Murphy [16] describe science, technology, economics, ecology, and political science as the foundation of sociotechnical transition theory based on multiple works [14,61-68]. The literature of sociotechnical transitions often focuses on the replacement of artifacts to achieve sustainability [69-72]. With increasing pressure on cities and their infrastructure due to flood risk, temperature rise, and other social and economic factors, cities have turned to various artifacts as a means to change course and promote sustainable practices. In this sense, artifacts are features embedded in society such as green infrastructure, new underground pipe infrastructure, etc. These artifacts or features provide the basis for the evaluation of a sociotechnical system; however, focusing only on artifacts limits the scope and the range of actors in play within a sociotechnical system. The full sociotechnical system must be considered.

Cities provide premier opportunities for sociotechnical transitions such as those regarding piped water systems in Europe or the electrical grid in New York City, described by Geels [8]. Additionally, sociotechnical transition case studies have evaluated the green building economy or ecovillages, providing insights into the changing trends of the green economy around the United States and England [73,74]. Cities can play three roles in sociotechnological transitions: primary actors, locations, or seedbeds for early phases of transitions, or limited roles [8]. These transitions can come in the form of four different types of regime changes (described in Hodson and Marvin [75]), with purposive transitions being the suggested norm for city-level sustainability progress. These studies of transitions are particularly important to geographers when addressing concerns of sustainability and why certain unsustainable developmental practices are constraining a region, city, or community [16]. 


\subsection{Urban Experiments}

The urban environment is a relatively new area for the application and assessment of sociotechnical transitions [75,76]. However, cities are increasingly using experimentation as a form of governance to generate a sustainable urban environment [77]. Urban experiments attempt to change material arrangements, cultures, norms, and conventions, and in the process, create a new political space $[18,78]$. Experimentation attempts to rework social and technical networks through multiple stakeholders and iterations over time [22,79]. When discussing sustainability transitions at the urban level, there are often existing regimes in place, including infrastructure, social practices, and economic investment that pose challenges to progressive change. Experimentation in an urban laboratory provides a means to overcome these existing regime challenges and advance a city's infrastructure and social interactions with sustainability goals $[15,80]$.

Current urban experimentation studies have a broad range of focus, which includes climate change mitigation strategies like those in the United Kingdom, Germany, and India [81-83], low carbon experimentation $[84,85]$, and smart urbanism [86,87]. The politics of creating these urban experiments to promote change facilitates questions of wider transformation [22]. The sociotechnical nature of urban experiments enables them as an adaptable framework. We present green infrastructure as a sociotechnical system that satisfies criteria of an urban experiment through its explicit break from the norm of gray infrastructure and through its requirement of new forms of governance, maintenance, and citizen participation.

\section{Developing an Experimental Framework}

Voß et al. [4] stated that future efforts in sociotechnical transition management should include a design of procedures for experimentation. While we do not attempt to provide a green infrastructure construction plan for all cities, we instead define a policy procedural framework for green infrastructure that is unified under similar governance challenges [88]. Green infrastructure construction, type, and size, on the other hand, depend on a large number of factors that vary by region and policy goals [55]. Literature reveals six requirements for the development of an experimentation framework for sociotechnical transitions:

1. Problem-oriented framework [89]

2. Flexible and adaptive [4]

3. Definitive system boundaries with controlled data collection [81]

4. Social learning/Capture interest of non-scientists $[4,90]$

5. Recursive/Implement experimental results [4,90]

6. Link between knowledge production and practices [91]

A meaningful assessment of sustainable development-including green infrastructure approaches-requires placement in a problem-oriented framework [89]. Framing green infrastructure as an experiment in sustainability provides this necessary framework. The associated policy for green infrastructure experimentation is an open-ended process, promoting sociotechnical transitions that require flexible and adaptive strategies to cope with the ever-changing sustainability landscape [4]. In the creation of an urban experimental framework, it is important to completely define system boundaries for controlled experimentation, data collection, and evaluation [81]. Stakeholders and their engagement in the learning process are essential to the propagation of the sociotechnical transition $[4,90]$. The experimental framework requires an iterative and recursive function that utilizes the results of implemented solutions and links policy, production, and practices $[4,90,91]$.

Urban experiments are sites of knowledge production that-when combined with a continuous feedback loop—create a recursive process of learning and data collection [21]. Pennell et al. [92] and Hildén [93] describe this process as a policy feedback cycle (PFC). This cyclical and recursive process aligns with the continuous feedback loop of experimentation in an urban environment [94,95]. Therefore, a PFC provides a suitable foundational framework for green infrastructure experimentation; see Figure 1. 


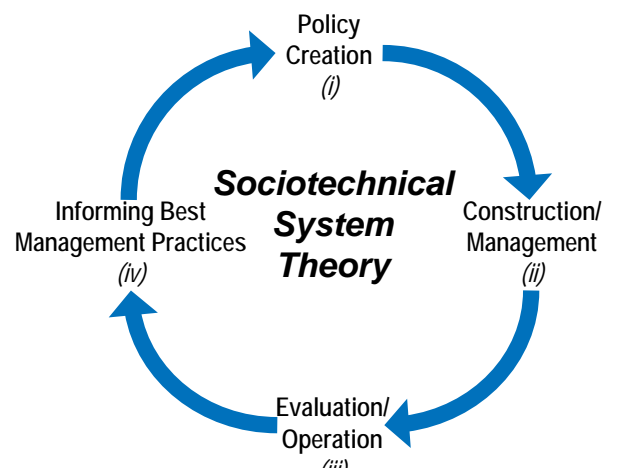

(iii)

Figure 1. A generalized policy feedback cycle lies within a sociotechnical perspective, and is inherently an experimental framework (modified from Pennell et al. [92]).

The PFC as an experimental framework (Figure 1) consists of four stages: (i) policy creation; (ii) construction/management; (iii) evaluation/operation; and (iv) informing best management practices. Using the six requirements for urban experiments described above, we expand on the framework for the PFC and further describe each of the four stages. Additionally, we describe key stakeholders within the sociotechnical system, including a knowledge broker to facilitate information transfer between experimental results and policy production [91,92]. Additionally, city governments-while in a prominent role-are not the only actors in the sociotechnical experimental framework. Other actors, such as private entities, non-profit organizations, and members of society play key roles in the development and success of a green infrastructure experimental framework [78]. Therefore, we expand the basic PFC in Figure 2.

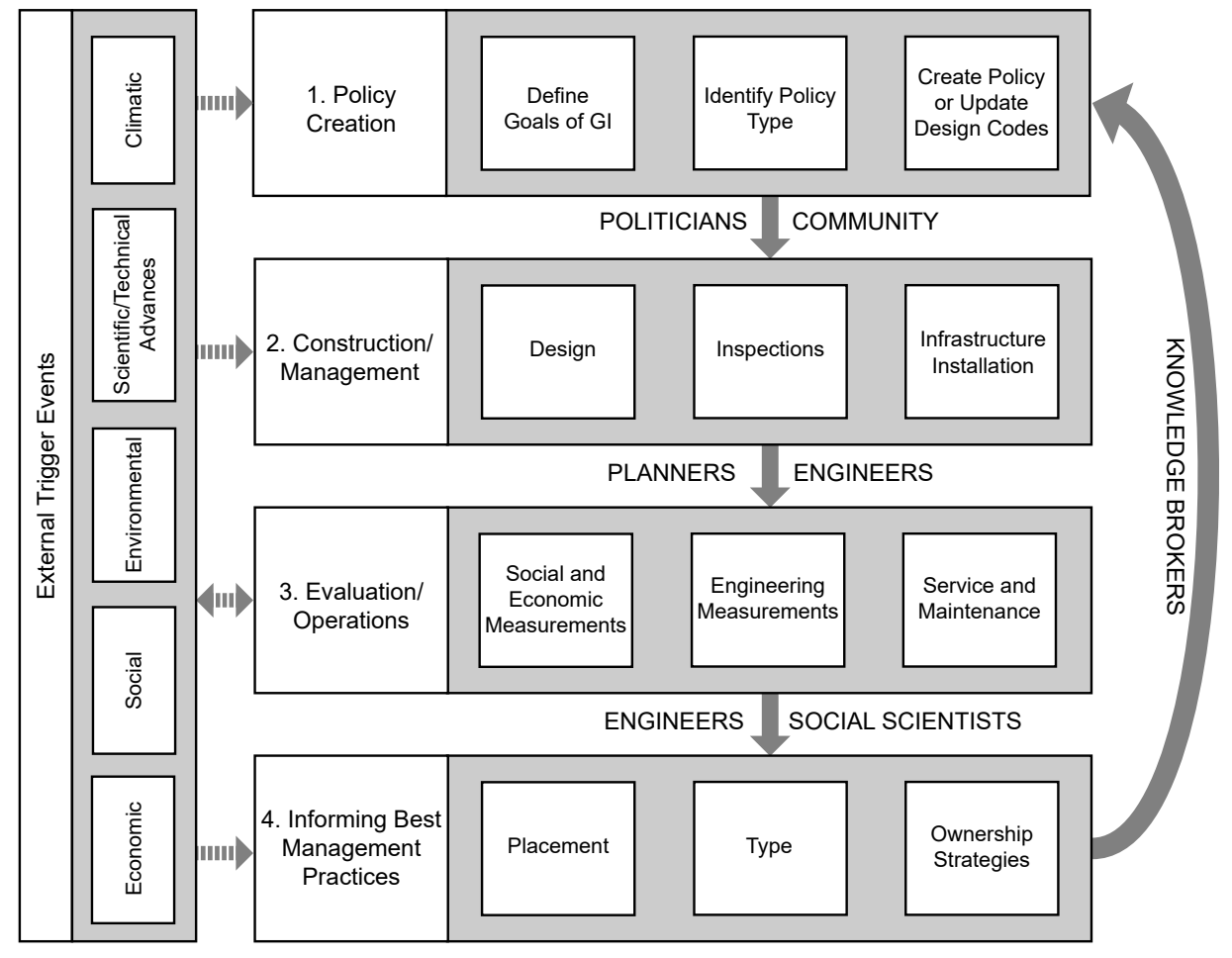

Figure 2. The sociotechnical system of the green infrastructure (GI) policy feedback cycle creates an experimental framework for decision-making. Each of the four main stages of the cycle includes important decisions or subtasks. Subtasks further describe the stage, but also provide the means to analyze the effectiveness of each stage through experimentation. Along the left side of the diagram are external trigger events that might interact with each of the four stages of the cycle. 


\subsection{Stages of the Policy Feedback Cycle}

Urban experiments seek to produce and test knowledge and provide evidence to inform future interventions [96]. The policy feedback cycle (PFC) provides an opportunity to enunciate the distinct processes involved in the urban experimentation of green infrastructure. For ease of display and discussion, each stage of the PFC is presented independently of one another in a logical sequence. However, it is important to note that some overlap of the distinct stages is likely within different municipalities, based on the organizational structure and infrastructure management system. For example, there might be slight overlap between the two stages construction/management and evaluation/operations; yet, it is still important that the sociotechnical system analyze the stages separately for clarity.

The first stage of the PFC is policy creation, driven either through external trigger factors or as a refinement of previous policy based on a transfer of information via a knowledge broker or multiple knowledge brokers (Section 3.2). The first of three components is defining the goals of the policy, where the system benchmarks for the experiment are declared with respect to green infrastructure implementation. Goals can be any combination of hydrologic measurements, environmental concerns, or social factors based on the motivation or external trigger of the green infrastructure policy. Second, the policymaker should determine the type of policy as either public ownership, regulation, mandates, or incentives [97]. Finally, the subsequent construction and management stage receives the updated policy or design code.

The second stage-construction and management-is the implementation or execution of the preceding policy through execution of design codes, incentives, or municipality-driven upgrades. This stage includes the design, inspection, and the physical building of infrastructure. The construction and management stage - not the evaluation stage-includes inspections, often mandated explicitly by policy or design codes. Conversely, the operations and evaluation stage is often in response to inspections of existing built infrastructure. Additionally, different management agencies within an organizational structure perform inspections and operations [98].

The third stage-evaluation and operations-evaluates system effectiveness, including routine operations and maintenance that are essential for the continued use and performance of the green infrastructure system. Maintenance is a learning process central to the work of urban experimentation [56]. The gathering and evaluation of engineering, social, and economic measurements are equally important. Experiments require a restructuring of flows, resources, power, and materials for the maintenance of infrastructure systems [56]. A variety of measurements and information gathering ensures the consideration of all three pillars of sustainability (environment, economy, society) for decision making in the final stage of the PFC.

Fourth, the informing best management practices stage of the cycle includes data synthesis and decision-making based on the previously collected and evaluated data. Decisions include making informed conclusions on the placement, type, and ownership strategies of green infrastructure. Ownership strategies pertain to both lessons learned from the operational side of the green infrastructure and the effectiveness of public versus privately implemented green infrastructure systems. Knowledge brokers communicate these decisions to the policy creation stage of the cycle, where the iterative process will ideally begin again [92].

\subsection{Key Stakeholders}

Sociotechnical systems are shaped by a broad audience of stakeholders, including engineers, policymakers, business interests, non-governmental organizations, and consumers [14]. Pope et al. [99] discuss stakeholders as an integral part of evaluation for sustainability. The policymakers are involved in the first step of the cycle- making the policy decisions and listening to the information following the evaluation of infrastructure. Engineers are involved in both the construction/management and the evaluation/operations steps of the process. Social scientists and urban planners participate in the evaluation and construction stages, respectively. Community involvement is a part of the 
policy creation stage, with opportunities for greater involvement throughout other stages of the PFC. To complete the cycle and create a recursive experiment, there is a need to link knowledge creation in the fourth stage of the cycle to the first stage-policy creation [91]. Pennell et al. [92] proposed the term "knowledge broker" as the intermediary between the experts evaluating the infrastructure and the policymakers making decisions. Knowledge brokers are involved on the back end of the evaluation process and entirely on the informing step of the cycle, with a working knowledge at all process stages. Implementing all steps of this feedback cycle with the participation of each stakeholder is essential in the creation and implementation of green infrastructure policy and systems in terms of sociotechnical systems. The role of knowledge brokers in municipalities' green infrastructure programs offers opportunities for universities, research organizations, non-profits, and others to play a major role in shaping and evaluating green infrastructure systems.

\subsection{External Trigger Events}

Often, external events-either in the form of disasters (natural or anthropogenic), rare climatic occurrences, new technologies, slow drivers (such as climate change), or a greater understanding of the environment-prompt policy decisions. Walsh et al. [100] describe these occurrences as "wildcard events" (specifically referring to disaster events), and discuss their importance in terms of prompting change from the norm and advancing systems for improvement. The transition literature describes these external events as landscape factors from a multi-level perspective [10]. These external trigger events, landscape factors, or wildcard events can be signs of the shortcomings of the existing gray infrastructure regime. For instance, two major driving forces cited for prompting green infrastructure measures in Chicago, IL, to mitigate stormwater runoff are combined sewer overflows and basement flooding [101]. Environmental trigger events include handling increased water volume demands and other water quality issues (e.g., CSOs). Social trigger events can come from communities or the public seeking and prompting change. Climatic trigger events are floods or long-term climate change. A dashed arrow in Figure 2 indicates the relation of external trigger events to the PFC. A double-headed arrow is included for the evaluation and operations phase of the feedback cycle to indicate potential evaluations leading to new technologies or scientific advances, which can in turn become external trigger events.

\section{Methodology}

The proposed PFC for green infrastructure provides opportunities to evaluate the green infrastructure experiment in cities across the United States. While the design of green infrastructure is also an experiment, we focus on the experimental nature of green infrastructure as a concept and means to further a regime change in stormwater management. The framework reduces to eight key questions that we apply to 27 cities across the United States; see Figure 3. We selected these cities based on their size and geographical spread across the United States. The answers to these questions provide the basis for comparing and evaluating green infrastructure in cities.

- Does the city have a green infrastructure plan?

- What motivates the city to adopt such a plan?

- Is the plan physically implemented by the city (i.e., public vs. private construction)?

- What green infrastructure installations are included in the plan?

- Is there a maintenance plan/budget?

- Are there plans for evaluation of the built infrastructure performance? Does the plan have a success point?

- Are there opportunities to revise the plan following evaluation?

- Who are the key players in the plans (e.g., departments, knowledge brokers, etc.)?

We answered these questions for each of the 27 cities in the study through analysis of published documents on city websites. The 27 cities have a total population of 31.5 million people, nearly $10 \%$ of the 2015 U.S. population. The median city population is 662,000 , with a maximum city population of 
8.5 million and a minimum population of 180,000 . The cities range spatially across the United States and encompass multiple climate zones. More cities are included in the eastern half of the country due to the population distribution in the United States.

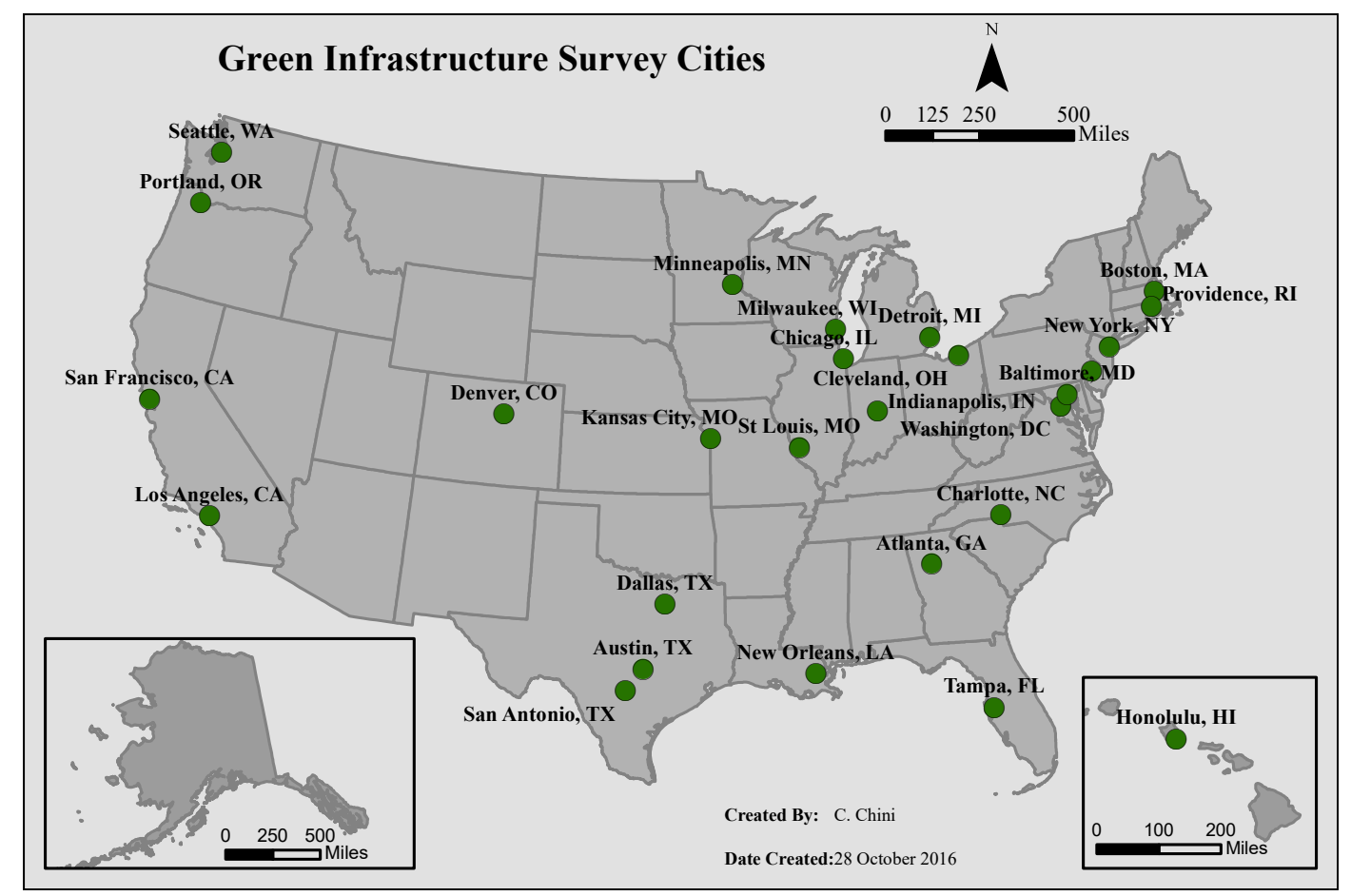

Figure 3. We evaluated 27 cities across the United States with relation to the policy feedback cycle and experimental framework.

We utilize this method of data collection from websites in lieu of submitting formal questionnaires to evaluate the public accessibility of green infrastructure information. While this approach relies on publicly available and published resources, it creates a standard platform for comparing results. We recognize the limitations of this methodology and the benefits of formal questionnaires or surveys; however, the sociotechnical nature of green infrastructure requires stakeholder involvement and communication of the plan to the public. Therefore, if any green infrastructure plans are not readily available to the public, we conclude that no plan is currently implemented in that city. The answers to the above questions provided several important insights to the current status of green infrastructure as an urban experiment.

\section{Comparative Urban Analyses}

Of the 27-city study, 21 cities have a specific green infrastructure plan, three have a less formalized plan, and three do not have a plan. It is equally important to identify both the stakeholders of the experiment $[18,20]$ and what the motivations of the experiment are (why they are experimenting) [96]. During our investigation of municipal green infrastructure plans, we collected information on motivations beyond water management. Many cities cited climate change as a purpose for their green infrastructure plan; others cited, for example, increased tree canopy (i.e., reduced heat island effect, improved air quality, etc.). There was a wide variety of motivations for the implementation of green infrastructure, even if a city did not have a formal plan. Table 1 displays the breakdown of each city's green infrastructure motivations, categorized into four broad areas: water quality, economic, environmental, and social. These sections help to highlight both the range of benefits that green infrastructure provides and the holistic approach policies are able to take to endorse its implementation. Cities that understand the sociotechnical advantages of green infrastructure list 
diverse motivations behind their plans, and subsequently record a higher number of check marks in the table. The cities of Portland, OR, Washington, DC, and San Francisco, CA demonstrated the largest number of motivations. Conversely, cities that lacked a formalized publicly-available green infrastructure plan (San Antonio, TX, Providence, RI, and Tampa, FL) each operate a municipal separate storm sewer system (MS4) and were among the cities that contained the fewest amount of motivations for disconnected green infrastructure projects within the city. Despite the absence of a formalized plan, however, these cities understood some of the benefits that green infrastructure offers.

Table 1. Motivations for implementing green infrastructure vary in cities across the country. The more boxes checked in a city reflect greater understanding of widespread green infrastructure as part of a sociotechnical system. The table was constructed based on the evaluation of each of the 27 cities' green infrastructure plans [35,101-159]. CSO: combined sewer overflow; EPA: US Environmental Protection Agency.

\begin{tabular}{|c|c|c|c|c|c|c|c|c|c|c|c|c|c|c|c|c|}
\hline \multicolumn{17}{|c|}{ Green Infrastructure Motivations } \\
\hline & \multicolumn{4}{|c|}{ Water Quality } & \multicolumn{5}{|c|}{ Economic } & \multicolumn{4}{|c|}{ Environmental } & \multicolumn{3}{|c|}{ Social } \\
\hline Cities & 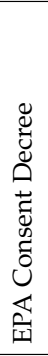 & 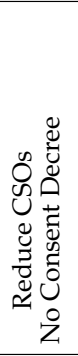 & 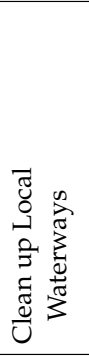 & 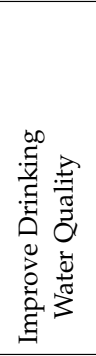 & 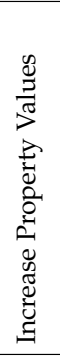 & 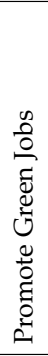 & 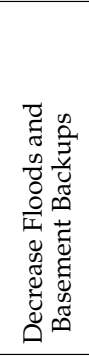 & 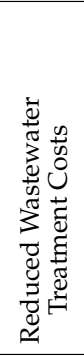 & 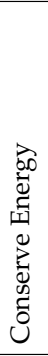 & 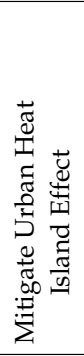 & 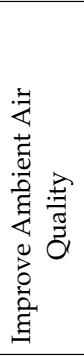 & 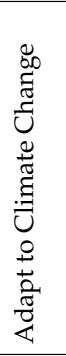 & 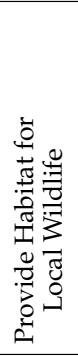 & 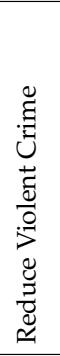 & 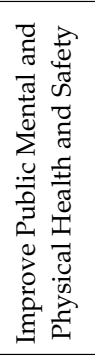 & 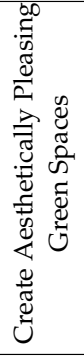 \\
\hline Atlanta, GA & & & & $\checkmark$ & $\sqrt{ }$ & & & & & & & & $\checkmark$ & & $\checkmark$ & $\checkmark$ \\
\hline Austin, TX & & & $d$ & & & & $\checkmark$ & & & & & & & & & 2 \\
\hline Baltimore, MD & & & 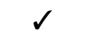 & & & & $\checkmark$ & & & $\checkmark$ & $\checkmark$ & & $\checkmark$ & & & $\checkmark$ \\
\hline Boston, MA & & & & & & & $\checkmark$ & & & $\checkmark$ & & $\checkmark$ & & & $\checkmark$ & $\checkmark$ \\
\hline Charlotte, NC & & & $\checkmark$ & & $\checkmark$ & & & & & & & & $\checkmark$ & & 4 & \\
\hline Chicago, IL & $d$ & & 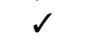 & & & & $d$ & & & & & $\checkmark$ & & & & \\
\hline Cleveland, $\mathrm{OH}$ & $\checkmark$ & & $\checkmark$ & & & & & & & & & & $\checkmark$ & & & \\
\hline Dallas, TX & & & 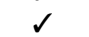 & & & & & & & & & & & & & \\
\hline Denver, CO & & & $\checkmark$ & & & & $\checkmark$ & & $\checkmark$ & $\checkmark$ & $\checkmark$ & $\checkmark$ & & & & $\checkmark$ \\
\hline Detroit, MI & $\checkmark$ & & $\checkmark$ & & $\checkmark$ & & & $\checkmark$ & & & & & & $\checkmark$ & $\checkmark$ & $\checkmark$ \\
\hline Honolulu, HI & & & & & & & & 1 & $\checkmark$ & & & & & & & \\
\hline Indianapolis, IN & $d$ & & $d$ & & & & & & & & & & & & & \\
\hline Kansas City, MO & $\checkmark$ & & $\checkmark$ & $\checkmark$ & & & $\checkmark$ & & & & & & & & $\checkmark$ & \\
\hline Los Angeles, CA & & & 2 & 2 & & & & & & & & & & & & \\
\hline Milwaukee, WI & & $\checkmark$ & 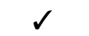 & & & & $\checkmark$ & & & & & & & & & \\
\hline Minneapolis, MN & & 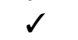 & 2 & & & & $\checkmark$ & & & & & & & & & \\
\hline New Orleans, LA & $\checkmark$ & & & & & & & & & $\checkmark$ & & & & & & \\
\hline New York, NY & 2 & & $d$ & & & & & & & & $\checkmark$ & & & & & $d$ \\
\hline Philadelphia, PA & $\checkmark$ & & 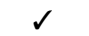 & & & & & & & & & & & & & $\checkmark$ \\
\hline Portland, OR & & $\checkmark$ & $\checkmark$ & & $\checkmark$ & & $\checkmark$ & $\checkmark$ & $\checkmark$ & $\checkmark$ & $\checkmark$ & $\checkmark$ & $\checkmark$ & & $\checkmark$ & $\checkmark$ \\
\hline Providence, RI & & & & $\checkmark$ & & & $\checkmark$ & & & & & & & & & \\
\hline San Antonio, TX & & & $\checkmark$ & & & & & $\checkmark$ & & & & & & & & \\
\hline San Francisco, CA & & & & & & $\checkmark$ & & 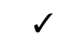 & $\checkmark$ & $\checkmark$ & $\checkmark$ & & $\checkmark$ & & $\checkmark$ & $\checkmark$ \\
\hline Seattle, WA & & $\checkmark$ & 2 & & $\checkmark$ & & & & & & & $\checkmark$ & & & & \\
\hline St. Louis, $\mathrm{MO}$ & & $\checkmark$ & 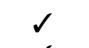 & & $\checkmark$ & & & & & & & & & & & \\
\hline Tampa, FL & & & $d$ & & & & & & & & & & & & & \\
\hline Washington, DC & $\checkmark$ & & $\checkmark$ & $\checkmark$ & $\checkmark$ & $\checkmark$ & $\checkmark$ & $\checkmark$ & $\checkmark$ & $\checkmark$ & $\checkmark$ & & & & & $\checkmark$ \\
\hline
\end{tabular}

Cleaning local waterways, consent decrees, decreasing flooding, and creating aesthetically pleasing green spaces are the most-cited drivers for green infrastructure adoption across the 27-city study (Table 1). Nine cities are motivated through consent decrees (legal mandates stating that the city is lawfully bound to decrease CSO volumes) and, consequently, incorporate green infrastructure as a part of their solution. All nine cities cited at least one additional motivation, thus showing recognition of green infrastructure benefits beyond the obligation of the decrees. Additionally, it is interesting to note that many cities cited cleaning local waterways as a motivation for green infrastructure; however, only a small subset of these cities cited improving drinking water quality as a motivation 
(Table 1). Many of these cities are upstream on rivers, and their local waterways affect other cities' drinking water quality, including many smaller municipalities on the same waterways that are not included in this study. The observation that many cities strive to clean up local waterways but not necessarily improve drinking water quality suggests an isolationist approach to water management and a limited-from a motivation perspective - understanding of the water cycle. Overall, such a variety of motivations shows diverse interpretation of the green infrastructure definition and its many benefits. Theoretically, all cities should recognize that most—if not all—of these motivations viably support green infrastructure implementation and ought to consequently craft initiatives that allow green infrastructure to reach its fullest potential across economic, environmental, and social lines.

Cities that have a green infrastructure plan usually incorporate both public and private measures to achieve their implementation goals. Five cities focus almost exclusively on public measures, while 16 of the cities utilize both private and public means to implement green infrastructure. Cities such as Seattle, WA, Austin, TX, Charlotte, NC, Chicago, IL, New Orleans, LA, Washington, DC, and Philadelphia, PA strongly encourage the installation of green infrastructure in new developments through legislation and post-construction runoff controls. For instance, Seattle, WA has requirements for on-site stormwater management, flow control, and treatment, and urges developers to utilize green infrastructure as a tool to fulfill all three requirements [157]. Additionally, local building codes such as those in New Orleans, LA needed updating to permit green roofs, rain gardens, and pervious pavement [158]. Several cities led the way in retrofitting existing public buildings with green infrastructure; Chicago, IL and Minneapolis, MN built green roofs on numerous municipal buildings [133,142]. Based on our study, cities with a public green infrastructure plan tend to have more ubiquitous implementation than plans with a private owner focus. Cities can utilize public spaces like parks, rights-of-way, streets, and alleyways. However, there is room for collaboration with homeowners and business owners who have space for green infrastructure elements.

There are multiple stakeholders in green infrastructure plans within the municipality itself. Municipal water authorities or water utilities lead green infrastructure projects in 17 of the evaluated cities. Of these cities, water authorities in five cities also work in collaboration with public works/ transportation departments. Six cities feature an exclusive department or task force dedicated to green infrastructure proliferation. We assert that such collaboration between city departments and water utilities is vital for the implementation of green infrastructure because green infrastructure affects a variety of entities. For instance, increasing tree canopy along a right-of-way also affects automobile drivers' line-of-sight, and incorporating a rain garden near an airfield might bring unwanted birds into the area. Engineers, landscape designers, environmental scientists, social scientists, and policymakers all offer unique expertise and perspective. Through collaboration, each can add value to green infrastructure projects to increase the effectiveness of green infrastructure.

Our study of green infrastructure plans yielded a large number of best management practices that cities label as green infrastructure. We present these different types of green infrastructure in categories pertaining to some of the motivations associated with green infrastructure plans; see Table 2. A majority of these measures targeted stormwater management through infiltration (e.g., permeable pavements, planter boxes) and plant uptake of water (rain gardens, increased tree canopy). One of the most popular measures was permeable pavement; 22 cities use permeable pavement as part of their green infrastructure implementation plan. Structural green infrastructure components included green roofs, cisterns (large scale rainwater harvesting), and blue roofs (non-vegetated source controls that detain and gradually release stormwater [118]). Furthermore, razing abandoned buildings and replacing the site with turf is a large part of St. Louis, MO's green infrastructure plan [154,159]. Additionally, Honolulu, HI named solar panels as green infrastructure measures [114], indicating the ambiguity of the phrase "green infrastructure" and that it does not just reflect stormwater management. Green infrastructure types are not exclusively tied to the goals listed, and feature secondary benefits; for example, increased tree canopy-besides providing water benefits in the form of stormwater uptake-also provides shade, reduces heat island effect, and creates habitat for wildlife. The variety 
in this list illustrates how cities use numerous means to define green infrastructure, emphasizing the need for flexible, iterative, location-specific decision-making. From a policy standpoint, this variation complicates defining green infrastructure universally. We therefore recommend that the definition of green infrastructure remain flexible and adaptable, allowing interpretation by cities based on local needs.

Table 2. Green infrastructure types vary widely based on system goals and motivation.

\begin{tabular}{|c|c|c|c|c|c|}
\hline \multicolumn{6}{|c|}{ Green Infrastructure Types and Goals } \\
\hline Infiltration & Transportation & $\begin{array}{l}\text { Natural } \\
\text { Systems }\end{array}$ & $\begin{array}{c}\text { Stormwater } \\
\text { Reuse }\end{array}$ & Buildings & Other \\
\hline $\begin{array}{l}\text { - Permeable } \\
\text { pavements } \\
\text { - Infiltration } \\
\text { planters / } \\
\text { Planter boxes } \\
\text { - Bioretention } \\
\text { areas } \\
\text { - Bioswales / } \\
\text { Biostrips } \\
\text { - Vegetated } \\
\text { detention } \\
\text { strips }\end{array}$ & $\begin{array}{l}\text { - Street } \\
\text { bumpouts } \\
\text { - Permeable } \\
\text { pavements } \\
\text { - Traffic } \\
\text { calming } \\
\text { bioretention }\end{array}$ & $\begin{array}{l}\text { - Increased } \\
\text { tree canopy } \\
\text { - Constructed } \\
\text { wetlands } \\
\text { - Restoration } \\
\text { of wetlands } \\
\text { - Creek } \\
\text { daylighting } \\
\text { - Abandoned } \\
\text { lot greening }\end{array}$ & $\begin{array}{l}\text { - Cisterns } \\
\text { - Rainwater } \\
\text { harvesting }\end{array}$ & $\begin{array}{l}\text { - Green roofs } \\
\text { - Blue roofs } \\
\text { - Cisterns }\end{array}$ & $\begin{array}{l}\text { - Non- } \\
\text { structural } \\
\text { measures } \\
\text { (policy) } \\
\text { - Solar panels }\end{array}$ \\
\hline
\end{tabular}

A majority of the cities recognize that operations and maintenance are important steps in accomplishing their green infrastructure goals. Of the 24 cities that have a structured green infrastructure plan, 19 include specific measures for maintenance. These measures include: providing resources for private landowners to maintain their green infrastructure, creating maintenance teams, and forging agreements with local businesses and homeowners to maintain green infrastructure. Additionally, several cities require municipal agencies to inspect these green infrastructure projects on private land. For instance, the Metropolitan St. Louis Sewer District requires that green infrastructure on private property be maintained by the owner and inspected by the agency [95]. Five of the twenty-four cities with green infrastructure plans do not include maintenance measures in their plans, which might prove troublesome in the long-term sustainability of the implemented green infrastructure measures. Maintenance is a critical process for the long-term success of green infrastructure experimentation and the learning process associated with it [56]. To implement a successful green infrastructure experiment, it is essential to include details on maintenance and operation.

It is important for cities to evaluate initial projects and to determine how to improve moving forward. Since green infrastructure plans are relatively new (i.e., within the last ten years) initiatives in many of the study cities, reiterating plans within the context of an urban experiment encourages learning and improved implementation of the green infrastructure system. Of the 24 cities with a green infrastructure plan, 15 outline how they will monitor existing or initial projects and craft adjusted policies or performance criteria to complete the PFC. Performance criteria are utilized in cities such as Atlanta, GA, where new and redeveloped sites must capture and treat the first $2.5 \mathrm{~cm}$ (1 inch) of rainfall on-site [104]. Furthermore, Baltimore, MD is striving to reach 40 percent tree canopy by 2037, and Honolulu, HI has programs in place that aim to install over 44 megawatts of power capacity through photovoltaic solar panels $[108,114]$. Five cities plan to monitor projects, but do not necessarily have a method to reiterate, and three cities do not have evaluation plans. Four cities (Chicago, IL, Boston, MA, Philadelphia, PA, and St. Louis, MO) have intentionally already used or plan to use the evaluation of green infrastructure to create new plans. Many cities cite water quality as a motivation for monitoring and evaluating the effectiveness of green infrastructure. While many of the studied cities take initiative to provide monitoring and evaluation frameworks, these documents are not always 
up to date, leaving the status of their green infrastructure plans in question. For example, the last Minneapolis Local Surface Water Management Plan update was in 2006 [143]. Policies can help ensure that the urban experiments are completing the proposed PFC to better address the effectiveness of green infrastructure.

It is common for green infrastructure to be a collaborative effort between municipal entities, water utilities, environmental groups, and local research universities and organizations. Municipal departments and regional water utilities often play lead roles. Other departments and environmental groups engage the lead players to ensure that green infrastructure is a readily-accepted solution for community involvement, speaking to their potential as knowledge brokers within the urban experimental framework. With a broad definition of green infrastructure, urban sustainability requires city leaders to collaborate with stakeholders equally as diverse as the green infrastructure techniques they implement.

\section{Discussion}

The process of developing the new green infrastructure technology within the urban environment requires an experimental and iterative mindset from policy. This experimental framework relies upon an iterative policy feedback cycle to implement green infrastructure in cities. We propose this framework not as a guide to specific green infrastructure, but as a means of developing the policy of green infrastructure across all cities. Revisiting the six requirements stated in the development of the experimental framework yields three interesting observations. (i) Defining system boundaries informs motivation and data collection; (ii) Capturing the interest of non-scientists and stakeholder involvement is paramount in the experimentation of green infrastructure; (iii) The recursiveness of the green infrastructure experiment is not fully visible in the current regime of stormwater management.

Green infrastructure is a sociotechnical system within the urban environment, requiring the integration of technical, engineering, policy, and social factors to develop and maintain a sustainable system. The variety of green infrastructure found during our study ranged from permeable pavements to wetland rehabilitation to photovoltaic solar panels; see Table 2 . This wide range of best management practices requires a flexible and fluid definition of green infrastructure from a policy perspective across cities. This definition reflects the defined system boundaries of an urban laboratory and is an important first step for cities [81]. Green infrastructure incentives at the national or state level would need to account for the fluid interpretation of these measures. Additionally, system boundaries are evident in the motivations of green infrastructure and vary between cities (Table 1). These motivations must inform the data collection process within the urban experiment system boundaries.

The first requirement of the societal laboratory identified by Latour [90] is that it must capture the interests of non-scientists-namely, the community. Green infrastructure as a sociotechnical system is predicated upon such community feedback and participation. One means of promoting feedback in the experimental framework is to provide important information to the public via municipality websites. This information could help to promote an understanding of the motivation for green infrastructure and create a more invested community in the plan. For example, Philadelphia publishes an interactive map with detailed information concerning green infrastructure throughout the city [160]. Philadelphia also features several nonprofits and other organizations that aspire to spread green infrastructure throughout that city, such as PlanPhilly, the Pennsylvania Horticulture Society, and PennEnvironment. Multiple cities in our study had web pages that had not been recently updated, with minimal readily accessible information. Governing policies date back a decade in some cities. A continuous social learning effort might help to promote the widespread implementation of effective green infrastructure. We highlight efficient communication as an important and vital tool for the implementation of green infrastructure as an urban experiment.

Finally, we propose the implementation of a recursive experimental framework to coincide with a policy feedback cycle that links knowledge production through a knowledge broker. Only 15 of the 24 cities with green infrastructure plans had plans to create an iterative process. This gap 
leaves opportunities for policies to focus on an urban experimentation framework for sustainable transitions in stormwater. There are opportunities for non-governmental organizations or research organizations to become knowledge brokers within the urban experimental framework. Utilizing an iterative experimental process for green stormwater infrastructure helps to further cities toward water resiliency. Our results indicate that cities recognize the need to progress into a twenty-first century stormwater management regime, and cite numerous motivations for the path forward. Simply implementing green infrastructure without monitoring or evaluation efforts does not aid in the transition towards sustainable stormwater infrastructure. Implementation of an iterative and circular process for experimentation is a priority for the propagation of sustainable design and sociotechnical transitions.

\section{Conclusions}

In this study, we synthesize urban experimentation and sociotechnical transition literature and apply it to green infrastructure. We present six requirements of an urban experimental framework and discuss them in relation to green infrastructure plans proposed by cities. We argue that a sociotechnical regime change is necessary in stormwater management, and an iterative experimental approach is required for this urban stormwater regime change. Our study provides an engineering perspective on the green infrastructure plans of 27 cities across the United States and the applicability of an urban experimental framework for the advancement of urban stormwater sustainability.

The required regime shift in urban stormwater can be facilitated through an experimental process. Successful experimentation is imperative in transforming the existing regime structure towards sustainability [17]. However, in describing the experimental framework, it is important to propound the metric of success [22]. Success metrics for green infrastructure experiments must be rooted in the motivation for the project. The experimental motivations inform the evaluation and operation stage and determine best management practices within the PFC. Sustainability by itself is not a valid motivation for urban experimentation; sustainability is so commonly utilized that it is no longer an authentic character [96]. Therefore, our results suggest future green infrastructure experiments embed themselves within the sociotechnical system and define their stakeholders and motivations to develop a manageable transition framework for urban stormwater sustainability.

Acknowledgments: This work was supported by the Department of Civil and Environmental Engineering at the University of Illinois at Urbana-Champaign. C.M.C. was supported by a National Science Foundation Graduate Research Fellowship. Any opinion, findings, and conclusions or recommendations expressed in this material are those of the author(s) and do not necessarily reflect the views of the National Science Foundation.

Author Contributions: Christopher M. Chini completed the analysis and wrote the manuscript; James F. Canning and Kelsey L. Schreiber assisted in the analysis and writing of the manuscript; Joshua M. Peschel and Ashlynn S. Stillwell supervised the analysis and assisted with writing the manuscript. Christopher M. Chini, Joshua M. Peschel, and Ashlynn S. Stillwell formulated the study.

Conflicts of Interest: The authors declare no conflict of interest.

\section{Abbreviations}

The following abbreviations are used in this manuscript:

CSO Combined Sewer Overflow

CSS Combined Sewer Systems

CWA Clean Water Act

EPA United States Environmental Protection Agency

GI Green Infrastructure

MS4 Municipal Separate Sewer Storm System

PFC Policy Feedback Cycle

\section{References}

1. Finco, A.; Nijkamp, P. Pathways to Urban Sustainability. J. Environ. Policy Plan. 2001, 3, 289-302. 
2. United Nations, Department of Economic and Social Affairs. World Urbanization Prospects, the 2014 Revision. Available online: http:/ / esa.un.org/unpd/wup/CD-ROM/ (accessed on 7 November 2016).

3. United Nations Conference on Environment and Development, 1992. Agenda 21. Available online: https: / / sustainabledevelopment.un.org/outcomedocuments/agenda21 (accessed on 15 October 2016).

4. Voß, J.P.; Smith, A.; Grin, J. Designing long-term policy: Rethinking transition management. Policy Sci. 2009, 42, 275-302.

5. Brown, R.; Keath, N.; Wong, T. Transitioning to water sensitive cities: Historical, current and future transition states. In Proceedings of the 11th International Conference on Urban Drainage, Edinburgh, UK, 31 August-5 September 2008; Volume 10.

6. Gunder, M.; Hillier, J. Planning in Ten Words or Less: A Lacanian Entanglement with Spatial Planning; Ashgate Publishing, Ltd.: Farnham, UK, 2009.

7. Finewood, M.H. Green Infrastructure, Grey Epistemologies, and the Urban Political Ecology of Pittsburgh's Water Governance. Antipode 2016, 48, 1000-1021.

8. Geels, F. The role of cities in technological transitions. In Cities and Low Carbon Transitions; Routledge: Abingdon-on-Thames, UK, 2011; pp. 13-28.

9. Rip, A.; Kemp, R. Technological Change; Battelle Press: Columbus, OH, USA, 1998.

10. Geels, F.W. Technological transitions as evolutionary reconfiguration processes: A multi-level perspective and a case-study. Res. Policy 2002, 31, 1257-1274.

11. Geels, F.W. From sectoral systems of innovation to socio-technical systems: Insights about dynamics and change from sociology and institutional theory. Res. Policy 2004, 33, 897-920.

12. Geels, F. Co-evolution of technology and society: The transition in water supply and personal hygiene in the Netherlands (1850-1930)—A case study in multi-level perspective. Technol. Soc. 2005, 27, 363-397.

13. Geels, F.W. Major system change through stepwise reconfiguration: A multi-level analysis of the transformation of American factory production (1850-1930). Technol. Soc. 2006, 28, 445-476.

14. Geels, F.W.; Schot, J. Typology of sociotechnical transition pathways. Res. Policy 2007, 36, 399-417.

15. Kemp, R.; Schot, J.; Hoogma, R. Regime shifts to sustainability through processes of niche formation: The approach of strategic niche management. Technol. Anal. Strateg. Manag. 1998, 10, 175-198.

16. Lawhon, M.; Murphy, J.T. Socio-technical regimes and sustainability transitions Insights from political ecology. Prog. Hum. Geogr. 2012, 36, 354-378.

17. Smith, A.; Raven, R. What is protective space? Reconsidering niches in transitions to sustainability. Res. Policy 2012, 41, 1025-1036.

18. Bulkeley, H.; Broto, V.C. Government by experiment? Global cities and the governing of climate change. Trans. Inst. Br. Geogr. 2013, 38, 361-375.

19. Brown, H.S.; Vergragt, P.J. Bounded socio-technical experiments as agents of systemic change: The case of a zero-energy residential building. Technol. Forecast. Soc. Chang. 2008, 75, 107-130.

20. Evans, J.P. Resilience, ecology and adaptation in the experimental city. Trans. Inst. Br. Geogr. 2011, 36, 223-237.

21. Karvonen, A.; Heur, B. Urban laboratories: Experiments in reworking cities. Int. J. Urban Reg. Res. 2014, 38, 379-392.

22. Evans, J.; Karvonen, A.; Raven, R. The Experimental City: New modes and prospects of urban transformation. In The Experimental City; Evans, J., Karvonen, A., Raven, R., Eds.; Routledge: New York, NY, USA, 2016; Chapter 1, pp. 1-12.

23. Brown, H.S.; Vergragt, P.; Green, K.; Berchicci, L. Learning for sustainability transition through bounded socio-technical experiments in personal mobility. Technol. Anal. Strateg. Manag. 2003, 15, 291-315.

24. Clark, W.C. Urban environments: Battlegrounds for global sustainability. Environment 2003, 45, 1.

25. Sexton, K.; Linder, S.H. Integrated assessment of risk and sustainability in the context of regulatory decision making. Environ. Sci. Technol. 2014, 48, 1409-1418.

26. Ottens, M.; Franssen, M.; Kroes, P.; van de Poel, I. Modelling infrastructures as socio-technical systems. Int. J. Crit. Infrastruct. 2006, 2, 133-145.

27. Pinch, T.J.; Bijker, W.E. The social construction of facts and artefacts: Or how the sociology of science and the sociology of technology might benefit each other. Soc. Stud. Sci. 1984, 14, 399-441.

28. Stone, D.A. Policy Paradox and Political Reason; Addison-Wesley Longman: Boston, MA, USA, 1988.

29. Grin, J.; van de Graaf, H. Implementation as communicative action. Policy Sci. 1996, 29, 291-319. 
30. Kemp, R.; Parto, S.; Gibson, R.B. Governance for sustainable development: Moving from theory to practice. Int. J. Sustain. Dev. 2005, 8, 12-30.

31. U.S. Environmental Protection Agency, Office of Water. Report to Congress: Impacts and Control of CSOs and SSOs. 2004. Available online: https://www.epa.gov/sites/production/files/2015-10/documents/ csossortc2004_full.pdf (accessed on 15 September 2016).

32. Benedict, M.A.; McMahon, E.T. Green Infrastructure; Island Press: Washington, DC, USA, 2006.

33. Grumbes, B.H. Using Green Infrastructure to Protect Water Quality in Stormwater, CSO, Nonpoint Source and Other Water Programs. United States Environmental Protection Agency (EPA). 2007. Available Online: https://www.epa.gov/sites/production/files/2015-10/documents/greeninfrastructure_ h2oprograms_07.pdf (accessed on 15 Septemeber 2016).

34. William, R.; Stillwell, A.S. Use of fragility curves to evalute the performance of green roofs. J. Sustain. Water Built Environ. 2016, in press.

35. City of Philadelphia: Philadelphia Water Department. Green City Clean Waters: Comprehensive Monitoring Plan. 2014. Available online: http://www.phillywatersheds.org/doc/GCCW_AmendedJune2011_ LOWRES-web.pdf (accessed on 31 October 2016).

36. Wang, R.; Eckelman, M.J.; Zimmerman, J.B. Consequential environmental and economic life cycle assessment of green and gray stormwater infrastructures for combined sewer systems. Environ. Sci. Technol. 2013, 47, 11189-11198.

37. Tzoulas, K.; Korpela, K.; Venn, S.; Yli-Pelkonen, V.; Kaźmierczak, A.; Niemela, J.; James, P. Promoting ecosystem and human health in urban areas using Green Infrastructure: A literature review. Landsc. Urban Plan. 2007, 81, 167-178.

38. Schilling, J.; Logan, J. Greening the rust belt: A green infrastructure model for right sizing America's shrinking cities. J. Am. Plan. Assoc. 2008, 74, 451-466.

39. Dunn, A.D. Siting green infrastructure: Legal and policy solutions to alleviate urban poverty and promote healthy communities. BC Environ. Aff. Law Rev. 2010, 37, 41.

40. Lee, A.; Maheswaran, R. The health benefits of urban green spaces: A review of the evidence. J. Public Health 2011, 33, 212-222.

41. Roe, J.J.; Thompson, C.W.; Aspinall, P.A.; Brewer, M.J.; Duff, E.I.; Miller, D.; Mitchell, R.; Clow, A. Green Space and Stress: Evidence from Cortisol Measures in Deprived Urban Communities. Int. J. Environ. Res. Public Health 2013, 10, 4086-4103.

42. Petit, J.; Bassert, D.L.; Kollin, C. Building Greener Neighborhoods: Trees as Part of the Plan; American Forests: Washington, DC, USA, 1995.

43. Hamilton, S.; Quayle, M. Corridors of green and gold: Impact of riparian suburban greenways on property values. J. Bus. Adm. Policy Anal. 1999, 30, 365.

44. Donovan, G.H.; Butry, D.T. Market-based approaches to tree valuation. Arborist News 2008, August, $52-55$.

45. Oberndorfer, E.; Lundholm, J.; Bass, B.; Coffman, R.R.; Doshi, H.; Dunnett, N.; Gaffin, S.; Köhler, M.; Liu, K.K.; Rowe, B. Green roofs as urban ecosystems: Ecological structures, functions, and services. BioScience 2007, 57, 823-833.

46. Baik, J.J.; Kwak, K.H.; Park, S.B.; Ryu, Y.H. Effects of building roof greening on air quality in street canyons. Atmos. Environ. 2012, 61, 48-55.

47. Santamouris, M. Regulating the damaged thermostat of the cities-Status, impacts and mitigation challenges. Energy Build. 2015, 91, 43-56.

48. William, R.; Goodwell, A.; Richardson, M.; Le, P.V.; Kumar, P.; Stillwell, A.S. An environmental cost-benefit analysis of alternative green roofing strategies. Ecol. Eng. 2016, 95, 1-9.

49. Malinowski, P.A.; Stillwell, A.S.; Wu, J.S.; Schwarz, P.M. Energy-Water Nexus: Potential Energy Savings and Implications for Sustainable Integrated Water Management in Urban Areas from Rainwater Harvesting and Gray-Water Reuse. J. Water Resour. Plan. Manag. 2015, 141, A4015003, doi:10.1061/(ASCE)WR. 1943-5452.0000528.

50. Turner, T. City as Landscape: A Post Post-Modern View of Design and Planning; Taylor \& Francis: Oxfordshire, UK, 1996.

51. Rudlin, D.; Falk, N. Building the 21st Century Home: The Sustainable Urban Neighbourhood; Butterworth-Heinemann: Oxford, UK, 1999. 
52. Lovell, S.T.; Taylor, J.R. Supplying urban ecosystem services through multifunctional green infrastructure in the United States. Landsc. Ecol. 2013, 28, 1447-1463.

53. Meerow, S.; Newell, J.P. Spatial planning for multifunctional green infrastructure: Growing resilience in Detroit. Landsc. Urban Plan. 2017, 159, 62-75.

54. Raven, R.P.; Heiskanen, E.; Lovio, R.; Hodson, M.; Brohmann, B. The contribution of local experiments and negotiation processes to field-level learning in emerging (niche) technologies meta-analysis of 27 new energy projects in Europe. Bull. Sci. Technol. Soc. 2008, 28, 464-477.

55. Gallo, C.; Moore, A.; Wywrot, J. Comparing the adaptability of infiltration based BMPs to various US regions. Landsc. Urban Plan. 2012, 106, 326-335.

56. Broto, V.C.; Bulkeley, H. Maintaining Climate Change Experiments: Urban Political Ecology and the Everyday Reconfiguration of Urban Infrastructure. Int. J. Urban Reg. Res. 2013, 37, 1934-1948.

57. Ahern, J. Green infrastructure for cities: The spatial dimension. In Cities of the Future: Towards Integrated Sustainable Water and Landscape Management; IWA Publishing: London, UK, 2007.

58. Long, S. Socioanalytic Methods: Discovering the Hidden in Organisations and Social Systems; Karnac Books: London, UK, 2013.

59. Emery, F. Characteristics of Socio-Technical Systems; Tavistock Institute of Human Relations: London, UK, 1959.

60. Badham, R.; Clegg, C.; Wall, T. Socio-technical theory. In Handbook of Ergonomics; John Wiley: New York, NY, USA, 2010.

61. Boschma, R.A.; Lambooy, J.G. Evolutionary economics and economic geography. J. Evol. Econ. 1999, 9, 411-429.

62. Dosi, G. Technological paradigms and technological trajectories: A suggested interpretation of the determinants and directions of technical change. Res. Policy 1982, 11, 147-162.

63. Freeman, C. Innovation, changes of techno-economic paradigm and biological analogies in economics. Rev. Écon. 1991, 42, 211-231.

64. Gunderson, L.; Holling, C. Panarchy: Understanding Transformations in Human and Natural Systems; Island Press: Washington, DC, USA, 2002.

65. Lall, S. Understandging technology development. Dev. Chang. 1993, 24, 719-753.

66. Nelson, R.R.; Winter, S.G. An Evolutionary Theory of Economic Change; Harvard University Press: Cambridge, MA, USA, 2009.

67. Norgaard, R.B. Coevolutionary development potential. Land Econ. 1984, 60, 160-173.

68. Van den Bergh, J.C. Evolutionary thinking in environmental economics. J. Evol. Econ. 2007, 17, 521-549.

69. Meadowcroft, J. Environmental political economy, technological transitions and the state. New Political Econ. 2005, 10, 479-498.

70. Meadowcroft, J. What about the politics? Sustainable development, transition management, and long term energy transitions. Policy Sci. 2009, 42, 323-340.

71. Shove, E.; Walker, G. CAUTION! Transitions ahead: Politics, practice, and sustainable transition management. Environ. Plan. A 2007, 39, 763-770.

72. Shove, E.; Walker, G. Governing transitions in the sustainability of everyday life. Res. Policy 2010, 39, 471-476.

73. Gibbs, D.; O'Neill, K. Rethinking sociotechnical transitions and green entrepreneurship: The potential for transformative change in the green building sector. Environ. Plan. A 2014, 46, 1088-1107.

74. Boyer, R.H. Grassroots innovation for urban sustainability: Comparing the diffusion pathways of three ecovillage projects. Environ. Plan. A 2015, 47, 320-337.

75. Hodson, M.; Marvin, S. Can cities shape socio-technical transitions and how would we know if they were? Res. Policy 2010, 39, 477-485.

76. Frantzeskaki, N.; Coenen, L.; Castán Broto, V.; Loorbach, D. (Eds.) Urban Sustainability Transitions; Routledge Studies in Sustainability Transitions: London, UK, 2017.

77. Bulkeley, H.; Broto, V.C.; Maassen, A. Low-carbon transitions and the reconfiguration of urban infrastructure. Urban Stud. 2014, 51, 1471-1486.

78. Broto, V.C.; Bulkeley, H. A survey of urban climate change experiments in 100 cities. Glob. Environ. Chang. 2013, 23, 92-102.

79. Berkhout, F. Normative expectations in systems innovation. Technol. Anal. Strateg. Manag. 2006, 18, $299-311$.

80. Nevens, F.; Frantzeskaki, N.; Gorissen, L.; Loorbach, D. Urban Transition Labs: Co-creating transformative action for sustainable cities. J. Clean. Prod. 2013, 50, 111-122. 
81. Evans, J.; Karvonen, A. ‘Give Me a Laboratory and I Will Lower Your Carbon Footprint!'—Urban Laboratories and the Governance of Low-Carbon Futures. Int. J. Urban Reg. Res. 2014, 38, 413-430.

82. Dorstewitz, P. Planning and experimental knowledge production: Zeche Zollverein as an urban laboratory. Int. J. Urban Reg. Res. 2014, 38, 431-449.

83. Boyd, E.; Ghosh, A. Innovations for enabling urban climate governance: Evidence from Mumbai. Environ. Plan. C 2013, 31, 926-945.

84. Bulkeley, H. Reconfiguring environmental governance: Towards a politics of scales and networks. Political Geogr. 2005, 24, 875-902.

85. Hodson, M.; Marvin, S. Making low-carbon England and Wales. Town Ctry. Plan. 2011, 79, 388-392.

86. Greenfield, A. Against the Smart City: A Pamphlet; Do Projects: London, UK, 2013.

87. Luque-Ayala, A.; Marvin, S. Developing a critical understanding of smart urbanism? Urban Stud. 2015, $52,2105-2116$.

88. Voß, J.P.; Bauknecht, D.; Kemp, R. Reflexive Governance for Sustainable Development; Edward Elgar Publishing: Cheltenham, UK, 2006.

89. Nill, J. Okologische innovationspolitik aus evolutorischer perspektive: Politikziel abstention, variation, oder gar selektion? (Ecological innovation policy from an evolutionary perspective: Abstinence, variation or even selection as policy objective?). In Institutioneller Wandel, Marktprozesse und Dynamische Wirtschaftspolitik: Perspektiven der Evolutorischen Okonomic. (Institutional Change, Market Processes and Dynamic Economic Policy: Evolutionary Economic Perspectives); Metropolis: Marburg, Germany, 2004; pp. 449-469.

90. Latour, B. Give me a laboratory and I will raise the world. In Science Observed; Sage: Thousand Oaks, CA, USA, 1983; pp. 141-170.

91. Marvin, S.; Silver, J. The urban labratory and emerging sites of urban experimentation. In The Experimental City; Evans, J., Karvonen, A., Raven, R., Eds.; Routledge: New York, NY, USA, 2016; Chapter 4, pp. 47-60.

92. Pennell, K.G.; Thompson, M.; Rice, J.W.; Senier, L.; Brown, P.; Suuberg, E. Bridging research and environmental regulatory processes: The role of knowledge brokers. Environ. Sci. Technol. 2013, 47, 11985-11992.

93. Hildén, M. Time horizons in evaluating environmental policies. New Dir. Eval. 2009, 2009, 9-18.

94. Brand, S. How Buildings Learn: What Happens after They're Built; Penguin: London, UK, 1994.

95. Graham, S.; Thrift, N. Out of order: Understanding repair and maintenance. Theory Cult. Soc. 2007, 24, 1-25.

96. Rapoport, E. The boundaries of experimentation in sustainable urbanism. In The Experimental City; Evans, J., Karvonen, A., Raven, R., Eds.; Routledge: New York, NY, USA, 2016; Chapter 6, pp. 77-87.

97. Bengston, D.N.; Fletcher, J.O.; Nelson, K.C. Public policies for managing urban growth and protecting open space: Policy instruments and lessons learned in the United States. Landsc. Urban Plan. 2004, 69, 271-286.

98. City of Chicago, Department of Water Management. Water Management Organization Chart. Available online: https://www.cityofchicago.org/city/en/depts/water/auto_generated/water_our_structure.html (accessed on 31 October 2016).

99. Pope, J.; Annandale, D.; Morrison-Saunders, A. Conceptualising sustainability assessment. Environ. Impact Assess. Rev. 2004, 24, 595-616.

100. Walsh, C.; Glendinning, S.; Castán-Broto, V.; Dewberry, E.; Powell, M. Are wildcard events on infrastructure systems opportunities for transformational change? Futures 2015, 67, 1-10.

101. City of Chicago: Office of the Mayor. Green Stormwater Infrastructure Strategy. Available online: https:// www.cityofchicago.org/content/dam/city/progs/env/ChicagoGreenStormwaterInfrastructureStrategy. pdf (accessed on 31 October 2016).

102. City of Atlanta Department of Watershed Management. Green Infrastructure for Single Family Residences. 2012. Available online: http:/ / www.atlantawatershed.org/default/?linkServID=32A08C06-9D55-4889-97FA CA852EBE559E\&showMeta=2\&ext=.pdf (accessed on 24 October 2016).

103. City of Atlanta Department of Watershed Management. Implementing Green Infrastructure: Atlanta's Post-Development Stormwater Ordinance. 2013. Available online: http://www.atlantawatershed. org/default/?linkServID=A49C0402-58B7-4594-B7A215B6F4BC48D3\&showMeta=2\&ext=.pdf (accessed on 24 October 2016).

104. City of Atlanta Department of Watershed Management. Green Infrastructure Stormwater Management Practices for Small Commercial Development. 2014. Available online: http://www.atlantawatershed. org/default/?linkServID=6B82F82F-5178-46B9-804C065FD9D912CC\&showMeta=2\&ext=.pdf (accessed on 24 October 2016). 
105. City of Austin Watershed Protection Department. Green Infrastructure Working Group. 2015. Available online: https:/ / austintexas.gov/page/green-infrastructure-working-group (accessed on 24 October 2016).

106. City of Austin Watershed Protection Department. Grow Green Programs, 2016. Available online: http: //www.austintexas.gov/content/1653/Programs/2539 (accessed on 24 October 2016).

107. Chesapeake Conservancy. Green Infrastructure Report: Baltimore City. 2015. Available online: http: //www.chesapeakeconservancy.org/images/Green_Infrastructure_Report_Final_10.14.15.pdf (accessed on 12 October 2016).

108. Blue Water Baltimore. Benefits of Green Infrastructure. 2016. Available online: https://www. bluewaterbaltimore.org/blog/tag/benefits-of-green-infrastructure/ (accessed on 12 October 2016).

109. Texas A\&M University. Stormwater Project: What is Green Infrastructure for Stormwater. 2014. Available online: http:/ / texaswater.tamu.edu/stormwater/dallas-green-infrastructure/758.html (accessed on 16 October 2016).

110. The City and County of Denver Public Works. Ultra Urban Green Infrastructure Guidelines. 2015. Available online: https://www.denvergov.org/content/dam/denvergov/Portals/705/documents/ ultra-urban-green-infrastructure-guidelines.pdf (accessed on 17 October 2016).

111. The City of Detroit Water and Sewerage Department. What Is Green Infrastructure and How Can It Help Detroit? 2016. Available online: http://www.detroitmi.gov/Government/Departments-and-Agencies/ Water-and-Sewerage-Department/Green-Infrastructure (accessed on 16 October 2016).

112. The City of Detroit Water and Sewerage Department. Green Infrastructure Projects. 2016. Available online: http:/ / www.detroitmi.gov/Government/Departments-and-Agencies/Water-and-Sewerage-Department/ Green-Infrastructure-Projects (accessed on 16 October 2016).

113. The Greening of Detroit. The Greening of Detroit. 2016. Available online: http://www.greeningofdetroit. com/who-we-are/about-us/ (accessed on 16 October 2016).

114. Hawaii Green Infrastructure Authority. Hawaii Green Energy Market Securitization Program. Available online: http:/ /gems.hawaii.gov/learn-more/ (accessed on 18 October 2016).

115. The City of Indianapolis and Marion County. SustainIndy Green Infrastructure. 2016. Available online: http: //www.indy.gov/eGov/City/DPW/SustainIndy/GreenInfra/Pages/GreenInfrastructureHome.aspx (accessed on 17 October 2016).

116. Milwaukee Metropolitan Sewerage District. Regional Green Infrastructure Plan. 2013. Available online: http:/ / www.freshcoast740.com/-/media/FreshCoast740/Documents/GI\%20Plan/Plan\%20docs/ MMSDGIP_Final.pdf (accessed on 18 October 2016).

117. Milwaukee Metropolitan Sewerage District. Fresh Coast Milwaukee Wisconsin. 2016. Available online: http:/ / www.mmsd.com/gi/green-infrastructure (accessed on 6 September 2016).

118. New York City Department of Environmental Protection. NYC Green Infrastructure Program. 2016. Available online: http://www.nyc.gov/html/dep/html/stormwater/using_green_infra_to_manage_ stormwater.shtml (accessed on 6 September 2016).

119. New York City Department of Environmental Protection. Green Infrastructure Performance Metrics Report. 2016. Available online: http://www.nyc.gov/html/dep/pdf/green_infrastructure/gi-performance-metricsreport-2016.pdf (accessed on 6 September 2016).

120. The City of Portland Oregon. Green Infrastructure. 2016. Available online: https://www.portlandoregon. gov/bes/34598 (accessed on 30 August 2016).

121. The City of Portland Bureau of Environmental Services. 2013 Stormwater Management Facility Monitoring Report. 2013. Available online: https://www.portlandoregon.gov/bes/article/563749 (accessed on 30 August 2016).

122. San Francisco Public Utilities Commission. What Is Green Infrastructure? 2015. Available online: http: / / sfwater.org/index.aspx?page=667 (accessed on 18 October 2016).

123. San Francisco Public Utilities Commission. Green Infrastructure Projects. 2015. Available online: http: / / sfwater.org/index.aspx?page=614 (accessed on 18 October 2016).

124. District Department of Transportation. Green Infrastructure. 2015. Available online: http://ddot.dc.gov/ GreenInfrastructure (accessed on 18 October 2016).

125. District of Columbia Department of Transportation. Greening DC Streets. 2014. Available online: http:/ /ddot.dc.gov/sites/default/files/dc/sites/ddot/publication/attachments/2014-0418-DDOT-GIGreeningDCStreets.pdf (accessed on 18 October 2016). 
126. City of Boston. Greenovate Boston 2014 Climate Action Plan Update. Available online: http://192.241.241. 150/wp-content/uploads/2015/02/Boston_CAP_Full_Report.pdf (accessed on 17 September 2016).

127. Boston Transportation Department. Boston Complete Streets "Projects". Available online: http: //bostoncompletestreets.org/topics/projects/ (accessed on 17 September 2016).

128. Boston Mayor's Office. Mayor Walsh Announces City of Boston Joins the Trust for Public Land's Climate-Smart Cities Program. Available online: http://www.cityofboston.gov/news/Default.aspx?id= 20101 (accessed on 17 September 2016).

129. Boston Mayor's Office. Mayor Walsh Announces City of Boston Receives Grant for Climate Change Preparedness. Available online: http:/ / www.cityofboston.gov/news/Default.aspx?id=20300 (accessed on 17 September 2016).

130. City of Charlotte. Charlotte Post Construction Stormwater Ordinance 102014. Available online: http:// charlottenc.gov/StormWater/Regulations/Documents/CityPCSO2014.pdf (accessed on 17 September 2016).

131. City of Charlotte. NPDES MS4 Permit Program Stormwater Management Program Plan. Available online: http:/ / charlottenc.gov /StormWater/SurfaceWaterQuality/Documents/FY16SWMgmtPlan.pdf (accessed on 17 September 2016).

132. Charlotte-Mecklenburg Storm Water Services. Watershed Protection. Available online: http://charlottenc. gov/StormWater/SurfaceWaterQuality/Pages/WatershedProtection.aspx (accessed on 17 September 2016).

133. City of Chicago. Chicago Green Stormwater Infrastructure Strategy 2014. Available online: https://www. cityofchicago.org/content/dam/city/progs/env/ChicagoGreenStormwaterInfrastructureStrategy.pdf (accessed on 28 August 2016).

134. City of Cleveland. City of Cleveland Water Pollution Control. Available online: http://www.clevelandwpc. com/?page_id=2618 (accessed on 20 September 2016).

135. City of Cleveland. The Cleveland Tree Plan 2015. Available online: http://www.city.cleveland.oh.us/sites/ default/files/forms_publications/ClevelandTreePlan.pdf (accessed on 20 September 2016).

136. Northeast Ohio Regional Sewer District. Stormwater and watersheds. Available online: http://www. neorsd.org/stormwater-watersheds.php (accessed on 20 September 2016).

137. Kansas City, Missouri Water Services Department. Overflow Control Plan 2012. Available online: https://www.kcwaterservices.org/wp-content/uploads/2013/04/Overflow_Control_Plan_Apri302012_ FINAL.pdf (accessed on 1 October 2016).

138. The City of Kansas City, Missouri. Consent Decree 2010. Available online: https://www.kcwaterservices. org/wp-content/uploads/2013/04/Consent-Decree.pdf (accessed on 1 October 2016).

139. City of Los Angeles Sanitation. Sustainability Initiatives. Available online: https://www.lacitysan.org/san/ faces/home/portal/s-lsh-es/s-lsh-es-si;jsessionid=1BdFuAbqSEYibL4o4kCYQCmeSOEuolNFKZPKpJQnSS cwGk8dfp_m!-423078769!285103338?_afrLoop=7318117351209644\&_afrWindowMode=0\&_afrWindowId= null\#!\%40\%40\%3F_afrWindowId\%3Dnull\%26_afrLoop\%3D7318117351209644\%26_afrWindowMode\%3D0\% 26_adf.ctrl-state\%3Di4wcxt7um_4 (accessed on 29 August 2016).

140. City of Los Angeles Stormwater Program. South LA Green Alley Master Plan. Available online: http:/ / www.lastormwater.org/green-la/south-la-green-alley-master-plan/, (accessed on 29 August 2016).

141. City of Los Angeles Stormwater Program. Green LA. Available online: http://www.lastormwater.org/ green-la/ (accessed on 29 August 2016).

142. Minneapolis Park and Recreation Board. 2014 Water Resources Report. Available online: https://www. minneapolisparks.org/_asset/npgjwo/water_resources_report_2014.pdf (accessed on 5 September 2016).

143. City of Minneapolis. Minneapolis Local Surface Water Management Plan 2006. Available online: http:// www.ci.minneapolis.mn.us/publicworks/stormwater/stormwater_local-surface (accessed on 5 September 2016).

144. City of New Orleans. The Plan for the 21st Century 2012. Available online: http://www.nola.gov/ city-planning/master-plan/ (accessed on 18 October 2016).

145. Philadelphia Water Department. Green Stormwater Infrastructure. Available online: http:/ / phillywatersheds.org/what_were_doing/green_infrastructure (accessed on 2 September 2016).

146. Philadelphia Water Department. Green City, Clean Waters Comprehensive Monitoring Plan 2014. Available online: http://www.phillywatersheds.org/doc/Revised_CMP_1_10_2014_Finalv2.pdf (accessed on 2 September 2016).

147. Philadelphia Water Department. Policy and Regulations. Available online: http://phillywatersheds.org/ what_were_doing/policy_regulations (accessed on 2 September 2016). 
148. City of Providence and Rhode Island Department of Environmental Management. RIPDES Small MS4 Annual Report. Available online: http:/ /www.providenceri.com/efile/6497 (accessed on 14 October 2016).

149. Providence Journal. Providence Gets Grant to Reduce Stormwater Runoff. Available online: http:/ / www.providencejournal.com/breaking-news/content/20131025-providence-gets-grant-to-reducestormwater-runoff.ece (accessed on 14 October 2016).

150. Green Infrastructure Coalition. Providence Metro Area. Available online: http://www.greeninfrastructureri. org/providence.html (accessed on 14 October 2016).

151. Environmental Protection Agency. Providence Green Infrastructure Project. Available online: https: //www3.epa.gov/region1/ProvGI/index.html (accessed on 14 October 2016).

152. City of San Antonio and Texas Commission on Environmental Quality. Permit to Discharge under the Texas Pollutant Discharge Elimination System. Available online: http://www.sanantonio.gov/Portals/0/Files/ RemembertheRiver/2011TPDESMS4Permit-NOWQ0004284000.pdf (accessed on 2 October 2016).

153. City of San Antonio Transportation and Capital Improvements. Storm Water Design Criteria Manual 2016. Available online: http://www.sanantonio.gov/Portals/0/Files/CIMS/Services/cosa-final-swdcm-jan-2016web-version.pdf (accessed on 2 October 2016).

154. Metropolitan St. Louis Sewer Department. CSO Volume Reduction Green Infrastructure Pilot Program 2012. Available online: http:/ / www.missouribotanicalgarden.org/Portals/0/Shaw\%20Nature\%20Reserve/PDFs/ horticulture/MSD/2012\%20Stormwater/20120619McCrary.pdf (accessed on 16 October 2016).

155. City of Tampa. Stormwater Programs and Services. Available online: http://www.tampagov.net/ stormwater/programs (accessed on 2 October 2016).

156. City of Tampa. City of Tampa Annual Report 2010. Available online: http://www.tampagov.net/sites/ default/files/stormwater/files/2010_ANNUAL_REPORT.PDF (accessed on 2 October 2016).

157. Seattle Department of Construction \& Inspections. Stormwater Code. Available online: http://www.seattle. gov/dpd/codesrules/codes/stormwater/ (accessed on 31 October 2016).

158. Sewerage and Water Board of New Orleans. Green Infrastructure. 2014. Available online: https:// www.swbno.org/documents/environmental/greeninfrastructure/GreenInfrastructurePlan.pdf (accessed on 31 October 2016).

159. Metropolitan St. Louis Sewer District. Combined Sewer Overflow Long-Term Control Plan Update Report. 2011. Available online: http://www.stlmsd.com/sites/default/files/education/448861.PDF (accessed on 31 October 2016).

160. Philadelphia Water Department. Green Stormwater Infrastructure Project Map. Available online: http:/ / phillywatersheds.org/BigGreenMap (accessed on 4 January 2017).

(C) 2017 by the authors; licensee MDPI, Basel, Switzerland. This article is an open access article distributed under the terms and conditions of the Creative Commons Attribution (CC-BY) license (http:/ / creativecommons.org/licenses/by/4.0/). 